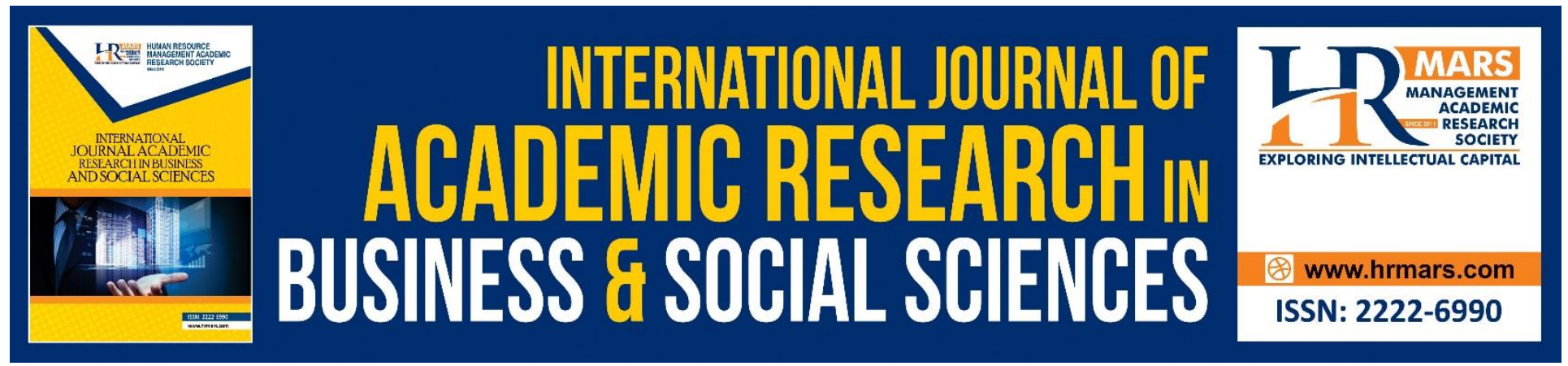

\title{
Leslie Parkes and N Thamendran Cases: The Question of Arrest Made by the Police and Military Authorities in Relation to the Armed Forces Absentees and Deserters in United Kingdom and Malaysia
}

Jamal Rodzi Dahari, Mazura Md Saman, Noor Hishmuddian Rahim

To Link this Article: http://dx.doi.org/10.6007/IJARBSS/v10-i8/7644

DOI:10.6007/IJARBSS/v10-i8/7644

Received: 03 June 2020, Revised: 06 July 2020, Accepted: 11 August 2020

Published Online: 29 August 2020

In-Text Citation: (Dahari, Saman, \& Rahim, 2020)

To Cite this Article: Dahari, J. R., Saman, M. M., \& Rahim, N. H. (2020) Leslie Parkes and N Thamendran Cases:

The Question of Arrest Made by The Police and Military Authorities in Relation to The Armed Forces

Absentees and Deserters in United Kingdom and Malaysia. International Journal Academic Research in

Business and Social Sciences. 10(8), 885-894.

Copyright: (c) 2020 The Author(s)

Published by Human Resource Management Academic Research Society (www.hrmars.com)

This article is published under the Creative Commons Attribution (CC BY 4.0) license. Anyone may reproduce, distribute, translate and create derivative works of this article (for both commercial and non-commercial purposes), subject to full attribution to the original publication and authors. The full terms of this license may be seen at: http://creativecommons.org/licences/by/4.0/legalcode

Vol. 10, No. 8, 2020, Pg. 885 - 894

http://hrmars.com/index.php/pages/detail/IJARBSS

JOURNAL HOMEPAGE

Full Terms \& Conditions of access and use can be found at http://hrmars.com/index.php/pages/detail/publication-ethics 


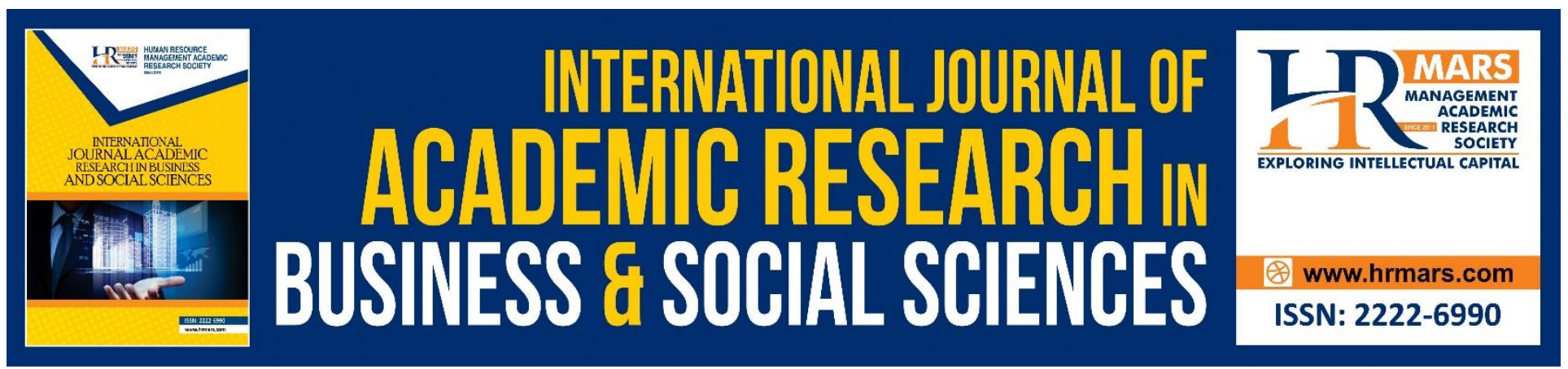

\title{
Leslie Parkes and $\mathbf{N}$ Thamendran Cases: The Question of Arrest Made by the Police and Military Authorities in Relation to the Armed Forces Absentees and Deserters in United Kingdom and Malaysia
}

Jamal Rodzi Dahari, Mazura Md Saman, Noor Hishmuddian Rahim

Faculty of Defence Studies and Management, National Defence University Malaysia

\begin{abstract}
The preponderancy of an arresting process is paramount in determining the legality of an arrest. An unlawful arrest may warrant dreadful consequences such as the writ of habeas corpus and claim for damages for unlawful detention or common law assault. The article seeks to examine the arrest procedure with regard to the offence of absence without leave and desertion in the Military Judicial System of the United Kingdom (UK) and Malaysia. The discussion shall briefly include the historical development of UK's military judicial system before the enactment of the UK's Armed Forces Act 1971 as well as the issues leading to the amendment of the Act in 1971 specifically in respect of the provision of the arrest for the offences mentioned above. The study is critical because the arrest clause appears in the Army Act 1955 (UK), which was later amended in UK's Armed Forces 1971 Act, is comparable in comparison to the arresting provision provided in Section 174 (4) of the Malaysian Armed Forces Act 1972. Essentially, while the UK Government has amended the Army Act 1955, the same provision is still applicable in Malaysia.
\end{abstract}

Keywords: Absence Without Leave, Arrest, Desertion, Malaysian Armed Forces Act 1972, UK Army Act 1955.

Introduction

In 2010, the High Court of Malaya, in the case of Sergeant N. Thamendran $v$ Govt of Malaysia \& Malaysian Armed Forces (Unreported), ruled that the applicant's detention for the offence of desertion under Section 93 (1),(3),(4) and (5) was wrong for failing to comply with the requirements of Section 174(4) of AFA 1972 and therefore his detention was illegal. Section 93 (1), (3) (4) and (5) of the AFA 1972 resembles in pari-materia to Section 74 of the Army Act 1955(UK) and Section 174 (4) of AFA 1972 resembles in pari-materia to Section 186 of the UK Army Act 1955. Ironically, while Section 93 and Section 174 of AFA 1972 is still in force in Malaysia, Section 74 and Section 186 of the UK Army Act 1955 has already been amended by the UK Armed Forces Act 1971 following the 
INTERNATIONAL JOURNAL OF ACADEMIC RESEARCH IN BUSINESS AND SOCIAL SCIENCES Vol. 10, No. 8, 2020, E-ISSN: 2222-6990 @ 2020 HRMARS

case of Leslie Parkes. It is therefore interesting to study what transpired in the Leslie case leading to such amendment and whether the Malaysian Armed Forces and Legislative should follow the moves by UK legislature. The discussion will also include the historical development of the Army Act 1955 (UK), which is relevant to the area of research. It also highlights the problems before and after the enforcement of the Armed Forces Act 1971 (UK).

\section{Historical Consideration of the Crown Military Law}

The conception of standing military forces was never an affinity during the period of miidle ages. Theoretically, any adult male with no disabilities was a soldier, liable to serve the city states either by feudal obligation or by virtue of being the subject of the King. The Sovereign of England commanded all military forces of the nation under the Royal Prerogative which gave the Sovereign the power to regulate and discipline the Army. The King would issue War Rules and Ordinances at the beginning of every war or campaign. These Rules and Ordinances was later known as the Articles of War were used to control troops. The Articles were severe, sanctioning death or loss of a limb for almost every crime. Commissions from the Crown provided the administration of military law, or by clauses inserted in the commissions of the commanders-in-chief authorising them to enact Ordinances for the government of the army under their command and in judgment themselves or appoint deputies (White, 2013). The powers of Armies Leader was plenary, and the punishment was eternally final (Rice, 1971, p. 48).

The situation slightly changed following the English Revolution. In 1689, the House of Commons proposed a proper regulation of the army which led to the enactment of the first Mutiny Act. The Act instituted the raising of a standing Army in the United Kingdom in time of peace and prohibited the forejudged of "life and limb" by martial law (See generally Lieber et al., 2019, p. 119). The passing of the Act was considered as the constitutional origin of the UK's standing army (Haughton, 1875, p. 45). Nevertheless, The Mutiny Act was to continue in force for one year only and subject to yearly renewal. The maintenance of the army was absolutely dependant upon the will of Parliament. If in any one year Parliament were not to be summoned, or refused to pass the Mutiny Act, The Army would dissolve of itself (Haughton, 1875, p. 45). Successive Mutiny Acts were passed annually from 1690 until 1878 (Sharma, 1973, p. 19). By then the parliament has been firmly granted the authority to control the army through the Crown's approval of the bills of rights. The Articles of War 1672 formed the groundwork of the Articles of War issued in 1878 which were later consolidated with the Mutiny Act in the Army Discipline and Regulation Act of 1879 which was in turn replaced by the Army Act of 1881(United States et al., 1930, p. 261). The 1881 Act constitute the military code for the British Army. Nevertheless, similar to the Mutiny Act, it was required to be brought into operation annually, to secure the constitutional of the control of the Parliament over the discipline required for the government of Army (United States et al., 1930, p. 261). A statutory power finally superseded the Crown's prerogative power of making Articles of War. The 1881 Act eventually, since 1917, was called the Army and Air Force (Annual) Act. The mandatory annual review provided for the possibility to amend the law, which has been used considerably (Sharma, 1973, p. 22). The introduction of Army Act 1955 changed the policy of annual renewal to the maximum total period of five years renewal by Orders in Council approved by both Houses of Parliament. By utilising these provisions, and an equivalent provision in subsequent Armed Forces Acts, the Army Act 1955 remained in force by annual Orders in Council and five-yearly Armed Forces Acts. The renewal of the Act was made through 
INTERNATIONAL JOURNAL OF ACADEMIC RESEARCH IN BUSINESS AND SOCIAL SCIENCES Vol. 10, No. 8, 2020, E-ISSN: 2222-6990 @ 2020 HRMARS

the Army and Air Force Act 1961, The Armed Forces Act 1966, 1971, 1976, 1981, 1991, 1996 and 2001.

In 2006, the UK parliament passed the Armed Forces Act 2006 to meet the global trend of joint-service operations. The Act introduced a single system of service law to meet the changing need. The main principles behind the Act are the traditional principles which underpin existing Acts, but with a harmonised approaches. They build on the evolution in-service law since the 1950s which has led to a system of service law that seeks to be fair and be seen to be fair, reinforce the link between command and discipline, be efficient and straightforward to use and not overburden commanding officers, be conducive to the expeditious application of justice, and 'transportable' anywhere in the world (Evans, 2009, p. 14).

\section{Arrest of Deserter and the Leslie Parkes Case Facts of The Case}

Leslie Parkes was military personnel enlisted in the Royal Ordnance Corps on 9 July 1963 for a nineyear engagement. On 3rd December 1965, he was given a formal warning as his general conduct was unsatisfactory. He would be discharged from the army if he failed to improve within three months. However, on 23 December 1965, he then left his team in Germany without permission. The police were informed about the matter. On 25 January 1966, he was recorded as absent without leave. Subsequently, on 23 June 1966, he was arrested by the police on the ground that there was reasonable cause to suppose him to be a deserter. But he insisted that he had completed military service. Later, he was taken before a Magistrate under the provisions of Sections 187 and 188 of the Army Act 1955 (Parkes, 1967). Parkes claimed that he joined the Army in 1962 for three-year engagement. He asserted that he left on completion of a three-year engagement, and his discharge papers supposedly were sent to him. After analysing the matter, the Magistrate was satisfied that he had completed military service, and he was released. A few months later, when the army authorities collected all available evidence to establish a case of absent on Parkes, he was rearrested by the military under Section 74 of the Army Act 1955 (Parkes, 1967).

\section{The Issue}

The issue involved in the case was on the appropriate procedure in arresting absentees and deserters.

\section{The Court's Decision}

There were doubts about the suitability of the arrest made under section 74 of the Army Act 1955 to a man who had been discharged by a magistrate under section 187 . The court held that, although it seemed contrary to the public interest for a person who had been discharged by a civil court under one section of the Act should be rearrested for the same offence by military procedures under a different section of the Act, but yet it is lawful (Arrest of Suspected Army Deserters, 1967).

\section{The Parkes Release due to Public Interest}

However, by taking the public interest factor, Parkes was released from military custody and immediately thereafter released from the army. The decision was made to avoid greater harm where the public interest will suffer if the case proceeds. The case later was dismissed (Ministry Of Defence (Absentees And Deserters), 1967). The civil police arrested Parkes on charges of perjury arising from 
INTERNATIONAL JOURNAL OF ACADEMIC RESEARCH IN BUSINESS AND SOCIAL SCIENCES

Vol. 10, No. 8, 2020, E-ISSN: 2222-6990 @ 2020 HRMARS

his appearance before the magistrates in 1966. He pleaded guilty at the Stafford Assizes to five charges of perjury and sentenced to 12 months' imprisonment. His application for leave to appeal against the sentence was rejected (The Case Of Mr Leslie Parkes, 1967).

\section{Areas of Uncertainties}

The case had attracted considerable attention in parliament and the Press. The parliament then realised that there were uncertainties in the existing law in two areas namely:

a) the application of Section 74 and Section 187 of the Army Act 1955 and;

b) the manner in which military discipline ceased when a soldier was released from civil custody.

The parliament decided that in the next review of the Army Act, consideration needs to be given in redefining the respective civil and military powers of arrest on absentees and deserters, and to providing, in the course of military disciplinary procedure some analogy to the civil processes of 'offering no further evidence' or entering 'Nolle prosequi'.

\section{The Consequences of the Case}

As the result of the inquiries into the arrest of Leslie Parkes on 9 February 1967, instructions have been issued to Army Home command that suspected absentees and deserters should not be arrested under section 74 of the Army Act 1955 unless they admit that they are soldiers. In addition to that, suspects arrested by the civil police and discharged by the magistrates should not be rearrested in the UK under section 74. Such instructions were incorporated in the Queen's Regulations.

\section{Amendment of the 1955 of The Army Act 1955}

After the Parkes case, the UK Legislation editorial team of the Armed Forces Act proposed the amendments to the provision of Sections 186 to 189 of the Army Act 1955 (as well as to the other service regulations) seeking to improvise the weaknesses identified in the 1955 Act. Sections 186 to 189 of the Army Act which confer special power of arrest by the police authorities in respect of persons suspected of desertion or absence without leave, and, by subsection (4), requires any person arrested under the provision to be brought before a court of summary jurisdiction was amended. by inserting the following:

"(4A) A person shall also be brought before a court of summary jurisdiction if, having been brought before such a court by virtue of subsection (4) above and discharged by that court by virtue of section 187 (3) below

(a) He is subsequently arrested as an alleged or suspected deserter or absentee without leave under section 74 of this Act, or under a warrant issued under section 190A thereof, and

(b) The question whether he is in fact in desertion or absent without leave raises any issue which was investigated by the court discharging him, and

(c) He does not admit that he is in desertion or absent without leave to the person arresting him under the said section 74 or, as the case may be, to the person into whose custody he is delivered pursuant to the said section 190A." (UK Armed Forces Act 1971, Section $186(4 A)$ ) 
INTERNATIONAL JOURNAL OF ACADEMIC RESEARCH IN BUSINESS AND SOCIAL SCIENCES Vol. 10, No. 8, 2020, E-ISSN: 2222-6990 @ 2020 HRMARS

The amendment sanctioned that a person who has been re-arrested as an alleged or suspected deserter or absentee by the military authorities under section 74 , still need to be brought before the magistrate even though he has been discharged for such offence before. The procedure provides a safeguard to the person arrested. Otherwise, after years of civilian life, anyone could unexpectedly found himself arrested by the military authority, held in military custody and tried before the courtmartial without ever appearing in the ordinary civil courts.

Another amendment made was on subsection (4) of section 187 of the Army Act 1955 that is in relation to the proceedings where a person brought before a court of summary jurisdiction as illegally absent. The sub-section was amended by inserting the following:

"(4A) For the purposes of any proceedings under this section, a certificate which states that a person is a member of, and illegally absent from, the regular forces, and purports to be signed by an officer who, if that person was charged with an offense, would be either his commanding officer or anybody authorized to act as his appropriate superior authority, shall be evidence of the matters so stated." (UK Armed Forces Act 1971, Section $187(4 \mathrm{~A}))$

Section 189 (3) of the Army Act 1955 in relation of the requirement of certificates of arrest or surrender of deserters and absentees to be evidence of the matters therein stated in the proceedings for offenses under sections 37 and 38 were also amended by inserting the following paragraph after paragraph $(a)$ :-

"(aa) where the proceedings are against a person who has surrendered himself to a consular officer, a certificate purporting to be signed by that officer and stating the fact, date, time and place of surrender shall be evidence of the matters stated in the certificate". (UK Armed Forces Act 1971, Section 189 (3)(aa)).

With the amendments to the provision of the arresting power of absentees and deserters in the UK Armed Forces Act 1971, certain procedures were incorporated into the Act. The procedure elucidates the relevant authorities on the appropriate actions to be taken in accordance with their responsibilities. With this procedure, it is assured that no violation of section 74 of the Army Act will occur. It aims to standardize all procedures of civil police on the arrest of absentees and deserters. According to Provost Manual of the United Kingdom, arrest of absentees and deserters can be made by two authorities that are by Military Police or by civil police. Arrest by the RMP may be divided into two that are 'unplanned operation' and 'planned operation'.

\section{Unplanned Operations}

In an unplanned operation, when military police see a person who is suspected of being an absentee they should approach the individual and identify themselves as a member of the military police (whether in uniform or not). The individual will be asked to introduce himself, and he needs to be informed about his suspicions. If the suspect admits the allegation, he will be cautioned and arrested before conveying him to the nearest custody centre (UK Provost Manual, Chapter 10). If he denies and refuses to give a reasonable explanation as to his identity, the assistance of civil police should be obtained. If the civil police are not available, then only the military police have the power to arrest the person under the authority of section 186 (2) of the Army Act 1955. The suspect so arrested must be brought before a court of summary jurisdiction as soon as possible. This will generally involve taking the suspect to a police station immediately following arrest and handing the person over to 
the civil police. The procedure also highlighted that although these powers are conferred on military police under the Army Act, such powers should only be used with great discretion and, in practice, only when the military police person knows full well that the individual is an absentee. (UK Provost Manual, Chapter 10)

\section{Planned Operations}

A planned Operation is when a deliberate and well-prepared plan is made to conduct the arrest. All available information is collected and the risks associated with the arrest evaluated. The absentee's unit will be contacted to confirm that the reported absentee is still absent and inquiring as to any known reasons for the absence. Information such as a photograph of the suspect, criminal record and the nature of the area of any next-of-kin address is located, and whether the civil police has already been to the place must be noted. This operation must be supported by civil police. On approaching the suspect, the same procedures in an unplanned operation will be applied. The search procedure must be done in accordance with the Service Police Codes of Practice. If the absentee is not wanted for any other crime and the reason for absence is not apparent, the absentee should be asked one question on the reason for his absence by the arresting or collecting person. The reason must be recorded in the Service Policeman's Notebook. When considering planned operations against absentees, thought must be given to any potential breach of Article 8 of the UK Human Right Act. To prevent such a breach, covert operations must be conducted in accordance with the Service Police Code of Practice.

\section{Absentees from other Services}

The Army Military Police in UK has reciprocal powers of arrest over members of the Royal Navy, Royal Air Force and Royal Marines. Nevertheless, there is an additional procedure applied to them when it involves other Services. Planned operations against members of other services should not be undertaken without reference to the appropriate Service Police Authority.

\section{Apprehension by Civil Police}

As the provision in section 186 empowers the civil police to arrest absentees and deserters, the procedures enacted include the general procedure for the civil police to perform the respective duties. This is as to harmonise action taken by all the enforcement authorities so that the actions are in accordance with the requirement of section 186 of the Armed Forces Act. Arrested suspect will be placed before a court of summary jurisdiction and thereafter informing the Local Military Police Unit in their area of the arrest requesting a copy of the arrest warrant or certificate. A certificate under Section 189 (1) of the Army Act 1955 will be signed by the Court and retained by the Police. The absentee will then be detained at the Police station until collected by the appropriate Military Police unit as detailed in Garrison Routine Orders. The civil police will hand over the absentee to the military escort. The suspect should not be re-arrested by the Military Police unit.

\section{Thamendran's Case}

Thamendran case also involves the question of arrest of absentees and deserter of an Armed Foces personel by Military Police. On $25^{\text {th }}$ November 2010, Sergeant N. Thamendran, personnel of the Royal Malaysian Air Force (RMAF), who was facing a charge of abetting theft of two F5 jet engines belonged 
INTERNATIONAL JOURNAL OF ACADEMIC RESEARCH IN BUSINESS AND SOCIAL SCIENCES Vol. 10, No. 8, 2020, E-ISSN: 2222-6990 @ 2020 HRMARS

to RMAF, was re-arrested by the RMAF provost officer on the grounds of absence from duty. He was alleged to have failed to report to his workplace after posting bail from the civil court on 6 Sept 2010 which constituted an offence of absence without leave under Section 55 (a) of AFA 1972. Thereafter, he was detained at the Military Detention Centre, Batu Kentomen Camp. Habeas corpus application was filed by Sergeant N. Thamendran demanding him to be released from detention. One of the ground of application by him was that the RMAF provost officer failed to comply with the provisions of Section 174 of the AFA 1972, which requires a person detained for offences of desertion and absence without leave to be taken before a magistrate. Hence, the arrest was an illegal arrest. RMAF on the other hand, argued that the arrest was legal by virtue of the provision of S 93 of the AFA 1972.

\section{Decision of the Court}

On hearing the arguments of the parties, the learned Judge of the High Court granted the writ of habeas corpus on the following grounds:

a) The Applicant's arrest was legally made pursuant to S 174 (2) AFA 1972.

b) Applicant's detention was wrong for failing to comply with the requirements of S 174 (4) of the AFA 1972. S 174 (4) requires the accused to be brought before a magistrate, within twenty-four hours, after his arrest, which was not done by the MPs in this case.

c) Provisions of S 93 (5) of the AFA 1972 cannot be invoked by the MPs since there was specific provision under S 174 (2) AFA 1972.

The High Court in coming to such decision relied on the application of the doctrine of specific law over general law (Generalibus specialia derogant). In the case PP v Chew Siew Luan ([1982] $2 \mathrm{ML}$ 119), Raja Azlan Shah C.J. (Malaya) (as he was back then) explain the maxim as "where a special provision is made in a special statute, that special provision excludes the operation of a general provision in the general law". Thus, the principle governing the rule of construction expressed in the maxim generalibus specialia derogant is that where there are two provisions of written law, one is general and the other is specific, the special or specific provision excludes the operation of the general provision (Luggage Distributor (M) Sdn. Bhd. V Tan Hor Heng [1995] 3 CL 520). It is therefore evident that in the event where the laws seem to contradict with one another, in finding a solution the courts are guided by the legal maxim Generalibus specialia derogant which means that where a special provision is made in a special statute, that special provision excludes the operation of a general provision in the general law. The courts agrees that when an Act enacts something in general terms and afterwards another on a particular subject introduces in express terms, special restrictions on that subject, then the rule of construction demands that the provisions in the subsequent particular legislation should prevail and the provisions of the earlier legislation deemed curtailed or restricted to the extent of its inconsistency with the later legislation but not necessarily repealed.

\section{Similarities and Differences of the two Cases}

In both cases Leslie and Thamendran, the earlier action of arrest military polices were questionable by the public at large and parliament in the case of Leslie and in the court of law in the case of Thamendran. It challenges involves the processes that should be followed by the Military police in their action of apprehending the deserters and absentees of the armed forces personnel. In the case of Leslie the ambiguous procedure have been rectified by the insertion of specific provisions in the 
INTERNATIONAL JOURNAL OF ACADEMIC RESEARCH IN BUSINESS AND SOCIAL SCIENCES Vol. 10, No. 8, 2020, E-ISSN: 2222-6990 @ 2020 HRMARS

UK Armed Forces Act 1971 as discussed above. The same has yet to be materialized in the case of Armed Forces Act 1972.

\section{Conclusion}

Since the initial drafting of the 1955 British Army Act of 1955 until today, it had experienced various amendments and improvements. The practice ofupdating the Act for every five years appears to be very effective in ensuring that all the relevant provisions in the Act remain current and relevant. The technical hitch demonstrated in the case of Leslie Parks were addressed by inserting new provisions in the subsequent UK Armed Forces Act 1971. In addition, the Military authority has also issued a clear procedure based on the newly amended provisions in the Act to be practised by the Military Police. In the case of Malaysian Armed Forces Act 1972, the Act still maintains the similar provision as the the UK Army Act 1955 which do no clearly define the respective functions of the civil and military authorities. The police have the power to arrest a deserter under Section 186, and the military authorities have powers under Section 74 to arrest a soldier for any offence against the Act. The Thamendran's case at least should send an alarming signals to the Military authorities to change their standard operating procedure, at least in the aspect of a arrest of the absentees and deserters of the Malaysian soldier, thus avoiding greater harm of civil suits arising out of illegal detention by military authority.

\section{References}

Arrest of Suspected Army Deserters (Hansard HL Deb 04 April 1967 vol 281 cc843-5). (1967). https://api.parliament.uk/historic-hansard/lords/1967/apr/04/arrest-of-suspected-armydeserters

Haughton, T. (1875). A summary of the principal events in English history. Oxford University.

Leslie Parkes (Arrest) (HC Deb 13 February 1967 vol 741 cc105-9; UK Hansard). (1967). https://api.parliament.uk/historic-hansard/commons/1967/feb/13/leslie-parkes-arrest

Lieber, F., Lieber, G. N., \& Smiley, W. (2019). To Save the Country: A Lost Treatise on Martial Law. Yale University Press.

Ministry of Defence (Absentees and Deserters). (1967). [Hansard]. https://hansard.parliament.uk/Commons/1967-10-25/debates/1705f388-71d4-4d92-b40d8cb4523253e4/MinistryOfDefence(AbsenteesAndDeserters)

Evans, N. (2009). The new Armed Forces Act of the United Kingdom. United Service, 60(3).

Rice, P. J. (1971). O'Callahan v. Parker: Court-Martial Jurisdiction, Service Connection, Confusion, and the Serviceman. Mil. L. Rev., 51, 41.

Sharma, O. P. (1973). Military Law in India. N.M. Tripathi.

The Case of Mr Leslie Parkes (Hansard HL Deb 26 October 1967 vol 285 ccl1773-6.). (1967). https://hansard.parliament.uk/Lords/1967-10-26/debates/425edd13-f321-4eea-aa8cae78c31b1f30/TheCaseOfMrLeslieParkes

The Case of Mr. Leslie Parkes (HL Deb 22 February 1967 Vol 280 Cc775-97 Hansard). (1967). https://api.parliament.uk/historic-hansard/lords/1967/feb/22/the-case-of-mr-leslie-parkes

United States, United States. Army. Office of the Judge Advocate General, \& United States. JudgeAdvocate General's Department (Army). (1930). Military Laws of the United States. U.S. Government Printing Office. 
INTERNATIONAL JOURNAL OF ACADEMIC RESEARCH IN BUSINESS AND SOCIAL SCIENCES Vol. 10, No. 8, 2020, E-ISSN: 2222-6990 @ 2020 HRMARS

White, A. S. (2013). A Bibliography of Regimental Histories of the British Army. Naval \& Military Press. 